\title{
Effect of different pre-boiling treatment on in vitro protein and amino acid digestibility of mung beans [Vigna radiata (L.) Wilczek]
}

\author{
Aree Prachansuwan ${ }^{1}$, Wantanee Kriengsinyos ${ }^{2 *}$, Kunchit Judprasong ${ }^{2}$, Attawit \\ Kovitvadhi ${ }^{3}$, \& Pipatpong Chundang ${ }^{3}$
}

${ }^{1}$ Graduate student in Doctor of Philosophy Programme in Nutrition, Faculty of Medicine Ramathibodi Hospital and Institute of Nutrition, Mahidol University, Nakhon Pathom, Thailand; ${ }^{2}$ Institute of Nutrition, Mahidol University, Nakhon Pathom, Thailand; ${ }^{3}$ Faculty of Veterinary Medicine, Kasetsart University, Bangkok, Thailand

\begin{abstract}
Introduction: Mung beans [Vigna radiata (L.) Wilczek] are good sources of protein. Nevertheless, its protein quality is still questionable. This study aimed to determine the effect of different processes prior to boiling, on the in vitro protein and amino acid digestibility of mung beans by using a 6-hour enzymatic digestion. Methods: This study was based on the household method of the processes before boiling including unsoaking, soaking, and dehulling. Products from all treatment methods were analysed for proximate composition (moisture, crude protein, crude fat, ash, and dietary fibre) on a dry basis, naturally occurring anti-nutritional factors, amino acid composition, and digestibility of protein and amino acids. The amino acid composition and amino acid digestibility were used to calculate the dietary protein quality. Results: The treatments prior to the boiling of mung beans such as dehulling, soaking and without soaking, improved protein digestibility significantly by $10.8 \%, 10.3 \%$, and $12.0 \%$, respectively, when compared with that of raw mung beans $(37.9 \%)$. Of the different mung bean pre-treatments, soaking seems to have the highest value of average indispensable amino acid (IAA) digestibility (55.4\%), in particularly branched-chain amino acids (66.4\%). However, there was no difference in the protein quality in terms of digestible indispensable amino acid score (DIAAS) across different treatment groups. Conclusion: The different processes performed on mung bean before boiling had only a slight impact on its amino acid digestibility and they rarely affected DIAAS values.
\end{abstract}

Keywords: Protein digestibility, protein quality, amino acid digestibility, DIAAS, pre-cooking treatment, mung bean

\section{INTRODUCTION}

Most developing countries meet their protein requirements by consuming mainly plant-based protein from sources such as legumes, seeds and pulses. These sources have recently received attention as they are environmentally friendly with a low-fat content and are cheaper than animal protein. However, the quality of plant protein is questionable (Henchion et al., 2017). Protein quality is important for human life and it is likely to have

\footnotetext{
*Corresponding author: Dr Wantanee Kriengsinyos Institute of Nutrition, Mahidol University, Nakhon Pathom, Thailand Tel: (+66)28002380 ext. 319; Fax: (+66)24419344; E-mail: wantanee.krieng@mahidol.ac.th doi: https://doi.org/ 10.31246/mjn-2019-0046
} 
several positive effects on growth and development as well as for promoting optimal health (FAO, 2013). High protein quality is needed to reduce childhood stunting which is associated with increased risk of metabolic diseases in later life (Arsenault \& Brown, 2017). The protein quality of food depends not only on the content of its indispensable amino acids (IAAs) but also on its digestibility and, therefore, its availability (FAO, 2013).

Legumes are the important sources of protein, energy and dietary fibre. Mung bean [Vigna radiata (L.) Wilczek] is one of the major economic crops and is widely consumed in Asia, particularly in South, East and Southeast areas of the continent. It can be consumed as both dehulled and whole bean to make a variety of main dishes, snacks, and desserts. Generally, they are used to complement local staple foods such as rice which is deficient in lysine (Singh, D'souza \& Yogitha, 2015). However, legumes have been reported to have low nutritive value because of the limited amounts of the sulphur-containing amino acids. It is also known that legumes contain several naturally occurring anti-nutritional factors, which are capable of inhibiting nutrient digestion and absorption (Gilani, Xiao \& Cockell, 2012).

At the household level, soaking and dehulling are common processing techniques that are used before cooking legumes. Thermal cooking, i.e. boiling, improves the edibility and palatability of legumes. Several studies have shown that the elimination of anti-nutrients through thermal cooking treatments improve protein digestibility (Mubarak, 2005; Gilani et al, 2012). In addition, boiling can increase protein content in mung beans, kidney beans, chickpeas, and faba beans (El-Moniem, 1999; Wang et al., 2010). With respect to amino acid composition, some studies have demonstrated increased concentrations of essential amino acids after cooking, while others have found reduced contents of methionine, tyrosine, and threonine (Candela, Astiasaran \& Bello, 1997; Alajaji \& El-Adawy, 2006). Although the boiling method has shown a reduction in anti-nutritive factors, a direct investigation of the impact of this process on the protein quality of mung beans has yet to be performed. In particular, studies of mung bean protein quality in terms of amino acid digestibility are scarce.

The Food and Agriculture Organization/World Health Organization (FAO/WHO) Expert Consultation on Protein Quality Evaluation has recommended the use of the Digestible Indispensable Amino Acid Score (DIAAS) method, which is based on the true ileal digestibility of each amino acid (FAO, 2013). It is necessary to consider amino acids as individual nutrients due to the differences in their bioavailability. Nevertheless, the collection of ileal fluid from the last part of the small intestine in human studies is very challenging and this invasive approach is the reason for the limited number of such studies. In vitro amino acid digestibility is one of the techniques that has been proposed to replace the time-consuming, costly, and invasive procedure to collect digesta from the terminal ileum, used in the in vivo evaluation of amino acid digestibility (Brulé \& Savoie, 1988). A previous study showed that processing methods such as extrusion, baking, and cooking had impacted differently on the amino acid digestibility and DIAAS values of red and green lentils (Nosworthy et al., 2018). Furthermore, soaking mucuna beans in different solutions followed by autoclaving also improved amino acid and protein digestibility (Siddhuraju \& Becker, 2005). However, to our knowledge, there is no study that has investigated the effect of different 
preparatory processes prior to boiling, which is a household preparation method, on the amino acid digestibility of mung beans.

The aim of the present work was to determine the effect of different treatment methods prior to boiling on the in vitro protein and amino acid digestibility of mung beans.

\section{MATERIALS AND METHODS}

\section{Materials}

The seeds of mung beans [Vigna radiata (L.) Wilczek] were purchased from a local market of Thailand for the various treatments. Prior to the processing and cooking treatments, the seeds were cleaned, and the immature seeds, dust, and unwanted particles were manually removed.

\section{Pre-thermal cooking treatment methods}

No pre-cooking treatment

Untreated seeds were boiled in distilled water ratio 1:10 (weight/volume) at $100 \pm 2{ }^{\circ} \mathrm{C}$ for $25 \mathrm{~min}$ on a hot plate, according to the procedure used in households.

\section{Soaking}

Seeds were soaked in distilled water for $7 \mathrm{~h}$ at room temperature, in accordance with the method of Devi et al. (2018). The soaked seeds were washed twice with distilled water and then boiled in the same way as the untreated mung beans.

\section{Soaking and dehulling}

Seeds were soaked in distilled water for $7 \mathrm{~h}$ at room temperature. After $7 \mathrm{~h}$, seed coats were manually removed and the dehulled mung beans were then boiled in the same way as the untreated mung beans.

\section{Preparation of samples}

The thermally cooked samples were ovendried at $50^{\circ} \mathrm{C}$ for $24 \mathrm{~h}$. The unprocessed raw seeds and dried cooked samples were ground in an electric grinder at $3500 \mathrm{rpm}$ for $1 \mathrm{~min}$, passed through a 120 -mesh screen and stored at $4^{\circ} \mathrm{C}$ in sealed plastic containers for further analysis.

\section{Proximate composition}

All samples were analysed for proximate composition (moisture, crude protein, crude fat, ash, and dietary fibre) in triplicate, by using standard methods of the Association of Official Analytical Chemists (AOAC) (AOAC International, 2016) and expressed on a dry basis. Moisture content was determined in accordance with AOAC method No. 990.19, by drying using a hot air oven at $100 \pm 2{ }^{\circ} \mathrm{C}$ until a constant weight was achieved. Total nitrogen was analysed according to Kjeldahl's method and calculated into protein content (Nx6.25) (AOAC method No. 991.20). The factor of 6.25 was used to convert nitrogen to protein, based on a report of a Food and Agricultural Organization Technical Workshop (FAO, 2002). Total fat was analysed by acid digestion prior to continuous extraction using ether in Soxtec system (AOAC method No. 948.15, 945.16). Ash content was determined by incinerating all organic matter at $550 \pm 5^{\circ} \mathrm{C}$ (AOAC method No. 945.46). Carbohydrate per 100 grams was calculated using the following formula: 100-moisture-protein-fat-ash; energy was calculated using the Atwater factor (4 for protein and carbohydrate and 9 for total fat). Dietary fibre was analysed using the enzymatic gravimetric method (AOAC method No. 985.29). 


\section{Naturally occurring anti-nutritional factors}

All samples were analysed in triplicate for phytic acid content, trypsin inhibitor activity, and tannin content.

\section{Phytic acid}

Phytic acid content was determined using the colorimetric method described by Gao (2007) with slight modification. Briefly, a $0.5 \mathrm{~g}$ sample was extracted with $10 \mathrm{~mL}$ of $2.4 \%$ hydrochloric acid $(\mathrm{HCl})$ by using shaker at $500 \mathrm{rpm}$ for $16 \mathrm{~h}$ and then centrifuged at $1000 \mathrm{~g}$ at $10^{\circ} \mathrm{C}$ for 20 min. One gram of sodium chloride $(\mathrm{NaCl})$ was added to the crude acid extract and shaken at $500 \mathrm{rpm}$ for $20 \mathrm{~min}$. The extract was allowed to settle at $-20^{\circ} \mathrm{C}$ for $20 \mathrm{~min}$ and then centrifuged at $1000 \mathrm{~g}$ at $10^{\circ} \mathrm{C}$ for $20 \mathrm{~min}$. The clear supernatant was diluted with distilled water, following which $3 \mathrm{~mL}$ of diluted sample was added with $1 \mathrm{~mL}$ of Wade reagent $\left(0.03 \% \mathrm{FeCl}_{3} \cdot 6 \mathrm{H}_{2} \mathrm{O}+0.3 \%\right.$ sulfosalicylic acid). The resulting solution was mixed and centrifuged at $1000 \mathrm{~g}$ at $10^{\circ} \mathrm{C}$ for 10 min. The absorbance of colour reaction products was read at $500 \mathrm{~nm}$ on UVvisible spectrophotometer. Phytic acid content was calculated against the standard curve.

\section{Trypsin inhibitor activity}

Trypsin inhibitor activity was determined using a colorimetric method (AACC International, 1999). One gram of sample was extracted in $50 \mathrm{~mL} 0.01 \mathrm{~N}$ sodium hydroxide $(\mathrm{NaOH})$ by stirring for $3 \mathrm{~h}$. The extraction solution was diluted with distilled water and trypsin solution was added at $37^{\circ} \mathrm{C}$, following which benzoylDL arginine-p-nitroanilide (BAPA) was added as a substrate. After $10 \mathrm{~min}$, the reaction was stopped by adding 1 $\mathrm{mL}$ acetic acid. The final solution was filtered through Whatman ${ }^{\circledR}$ filter paper No.2, before measurement of absorbance at $410 \mathrm{~nm}$ using spectrophotometer. Trypsin inhibitor activity was reported in terms of trypsin units inhibited. One trypsin inhibitory unit (TIU) was defined as an increase of 0.01 absorbance units per $10 \mathrm{~mL}$ of the reaction mixture.

\section{Tannin}

Tannin was determined colorimetrically by the vanillin- $\mathrm{HCl}$ method (Burns, 1971). All samples were extracted with methanol at $28^{\circ} \mathrm{C}$ for $12 \mathrm{~h}$. The decanted methanol extract was made up to $25 \mathrm{~mL}$ and filtered with Whatman ${ }^{\circledR}$ filter paper No.1. One $\mathrm{mL}$ of the extract was then treated with $5 \mathrm{~mL}$ of reagent mixture $(1: 1,4 \%$ vanillin in methanol and $8 \%$ concentrated $\mathrm{HCl}$ in methanol). The absorbance of the resultant colour was read on a spectrophotometer at 500 $\mathrm{nm}$ after $20 \mathrm{~min}$, using catechin as the reference standard. The tannin content was then calculated from a standard curve.

\section{Amino acid analysis}

The amino acid composition was determined by AOAC method No. 994.12 (AOAC International, 2016). Briefly, protein sources and dialysates were suspended in $10 \mathrm{~mL}$ of $6 \mathrm{M} \mathrm{HCl}$ with nor-leucine as an internal standard, in vacuum hydrolysis tubes at $121-123^{\circ} \mathrm{C}$ for $3 \mathrm{~h}$. The suspension was diluted to $20 \mathrm{~mL}$ with $2 \mathrm{M} \mathrm{NaOH}$ and then filtrated through Whatman ${ }^{\circledR}$ filter paper No.42 and syringe filter with pore size $0.45 \mu \mathrm{m}$; $100 \mu \mathrm{L}$ of filtrate was derivatized by $\mathrm{N}$, O-bis(trimethylsilyl) trifluoroacetamide (BSTFA) with 1\% trimethylchlorosilane (TMCS) prior to injection to gas chromatography-mass spectrometry (GCMS/MS).

The instrumental conditions for the GC-MS/MS (mass spectrometer) analyses were as follows: helium carrier gas was passed at a flow rate of $3.0 \mathrm{~mL} / \mathrm{min}$ through the HewlettPackard HP-5MS column (30 m x 0.25 $\mathrm{mm}$ (5\%-phenyl)-dimethyl-polysiloxane column, film thickness $0.25 \mu \mathrm{m})$. The 
inlet temperature was set at $250^{\circ} \mathrm{C}$. Two $\mu \mathrm{L}$ of prepared sample was injected using split mode in the ratio $3: 1$, with split flow rate of $3 \mathrm{~mL} / \mathrm{min}$. The GC oven temperature was increased from $100^{\circ} \mathrm{C}$ to $300^{\circ} \mathrm{C}$ at $15^{\circ} \mathrm{C} / \mathrm{min}$. The MS source and quadrupole temperatures were set at $230^{\circ} \mathrm{C}$ and $150^{\circ} \mathrm{C}$, respectively. The MS was run in the multiple-reaction monitoring acquisition mode. Data were obtained in the full scan mode with a scan range from $\mathrm{m} / \mathrm{z} 50$ to 550. Data were collected and integrated with a personal computer using MassHunter Software.

The contents of amino acids were analysed in duplicate and presented as $\mathrm{mg} / \mathrm{g}$ protein. The IAAs of each sample were compared with the recommended reference patterns for children aged 6 months to $<3$ years, older children aged $\geq 3$ years, adolescents, and adults (FAO, 2013).

\section{In vitro protein and amino acid digestibility evaluation}

The in vitro digestion procedure was performed in triplicate and based on a two-step proteolysis with pepsin and pancreatin as described by Brulé \& Savoie (1988), with minor modification. Each sample containing $250 \mathrm{mg}$ protein (40 mg nitrogen) was suspended in 16 $\mathrm{mL}$ of $0.1 \mathrm{M} \mathrm{HCl}$ and stirred for $10 \mathrm{~min}$ at $37^{\circ} \mathrm{C}$. The $\mathrm{pH}$ was adjusted to 1.9 , and the hydrolysis reaction was initiated by adding $1 \mathrm{~mL}$ pepsin solution (1 mg/ $\mathrm{ml}$ in $0.1 \mathrm{M} \mathrm{HCl}$ ) and carried out for 30 min. The enzymatic reaction was stopped by adjusting the $\mathrm{pH}$ to 7.5 with $1 \mathrm{M}$ $\mathrm{NaOH}$ and then poured into the dialysis bag [Spectra/Por ${ }^{\circledR}$ 6, molecular weight cut-off (MWCO) of $1 \mathrm{kDa}$, Spectrum Laboratories, Inc., LA, CA] of the digestion cell. The pancreatin solution $(10 \mathrm{mg} / \mathrm{ml}$ in $0.01 \mathrm{M}$ sodium phosphate buffer solution, $\mathrm{pH}$ 7.5) was added to the mixture. The digestion products were dialysed to the outer compartment of the cell and collected by circulating 0.01 $M$ sodium phosphate buffer solution $(\mathrm{pH} 7.5)$ at a rate of $1.4 \mathrm{~mL} / \mathrm{min}$ with a peristaltic pump for $6 \mathrm{~h}$ at $37^{\circ} \mathrm{C}$.

The collected solution was evaporated by a rotary evaporator (Model R-124, BÜCHI, Switzerland) and adjusted to a final volume. Amino acid contents of the collected solution were determined according to the procedure mentioned earlier. Nitrogen contents of the dialysate were measured by Kjeldahl's method. The in vitro protein and amino acid digestibility were calculated by the following formulae:

$\begin{aligned} & \text { Protein } \\ & \text { digestibility } \\ & (\%)\end{aligned}$
$\begin{aligned} & \text { Amino acid } \\ & \begin{array}{l}\text { digestibility } \\ (\%)\end{array}\end{aligned}$
$\begin{aligned} & \text { sample } \times 100 \\ & \text { protein in sample }\end{aligned}$
$\begin{aligned} & \text { amino acid in dialysed } \\ & \text { sample } 100\end{aligned}$

Dietary protein quality determination On the basis of protein quality, Amino Acid Score (AAS) and DIAAS were calculated as follows:

$$
\begin{aligned}
& \text { AAS }= \frac{\text { amino acid content in }}{1 \text { gram of test protein }} \\
& \text { amino acid content in } \\
& 1 \text { gram of reference protein } \\
& \text { DIAAS }=\begin{array}{l}
\text { lowest digestible } \\
\text { reference ratio }
\end{array}
\end{aligned}
$$

The recommended reference pattern of IAA profile was the amino acid requirement pattern for children aged 6 months to $<3$ years (FAO, 2013).

\section{Statistical analysis}

All data were expressed as mean \pm standard deviation (SD). Statistical differences between treatments were analysed by using one-way analysis of variance (ANOVA) and Tukey's test where 
Table 1. Proximate composition and naturally occurring anti-nutritional factors of mung bean (per 100 g dry weight)

\begin{tabular}{lcccc}
\hline \multirow{2}{*}{ Component } & Raw & \multicolumn{3}{c}{ Cooked } \\
\cline { 4 - 5 } & & Unsoaked & Soaked & $\begin{array}{c}\text { Soaked } 8 \\
\text { dehulled }\end{array}$ \\
\hline Moisture (g/100 g fresh sample) & $10.36^{\mathrm{a}}$ & $61.76^{\mathrm{b}}$ & $71.85^{\mathrm{c}}$ & $72.40^{\mathrm{c}}$ \\
Proximate composition & & & & \\
Energy (kcal) & $394^{\mathrm{a}}$ & $399^{\mathrm{b}}$ & $397^{\mathrm{c}}$ & $4^{\mathrm{b}}$ \\
Crude protein (g) & $25.95^{\mathrm{a}}$ & $27.37^{\mathrm{b}}$ & $27.66^{\mathrm{b}}$ & $29.04^{\mathrm{c}}$ \\
Crude fat (g) & $1.62^{\mathrm{a}}$ & $1.53^{\mathrm{a}}$ & $1.15^{\mathrm{b}}$ & $2.18^{\mathrm{c}}$ \\
Total carbohydrate (g) & $68.97^{\mathrm{a}}$ & $68.91^{\mathrm{a}}$ & $69.05^{\mathrm{a}}$ & $67.09^{\mathrm{b}}$ \\
Ash (g) & $3.47^{\mathrm{a}}$ & $2.18^{\mathrm{b}}$ & $2.14^{\mathrm{b}}$ & $1.69^{\mathrm{c}}$ \\
Dietary fibre (g) & $12.15^{\mathrm{a}}$ & $12.86^{\mathrm{b}}$ & $15.16^{\mathrm{c}}$ & $13.60^{\mathrm{d}}$ \\
Natural anti-nutritional factors & & & & \\
Phytic acid (mg/g) & $1.28^{\mathrm{a}}$ & $0.86^{\mathrm{b}}$ & $0.79^{\mathrm{b}}$ & $0.71^{\mathrm{b}}$ \\
$\quad \%$ reduction & & 32.38 & 37.85 & 43.95 \\
Trypsin inhibitor (TIU/mg protein) & 15.47 & $\mathrm{ND}$ & $\mathrm{ND}$ & $\mathrm{ND}^{\mathrm{b}}$ \\
$\quad \%$ reduction & & 100 & 100 & 100 \\
Tannin (mg/g) & $2.40^{\mathrm{a}}$ & $0.76^{\mathrm{bc}}$ & $0.64^{\mathrm{c}}$ & $0.97^{\mathrm{b}}$ \\
$\quad \%$ reduction & & 68.23 & 73.15 & 59.36 \\
\hline
\end{tabular}

Data were expressed as mean. The values within the same row with different superscript letters showed significantly differences between treatments at $p<0.05$, by one-way ANOVA with Tukey test. ND-Not detected

$p<0.05$ was considered as statistically significant. Statistical analysis was performed using SPSS software version 17.0 (IBM Corp., Armonk, NY).

\section{RESULTS AND DISCUSSION}

\section{Proximate composition and naturally occurring anti-nutritional factors of mung bean}

The proximate composition of raw and cooked mung bean seeds is presented in Table 1 . The protein content of mung beans ranged from 26 to $29 \mathrm{~g} / 100 \mathrm{~g}$ dry matter in this study. These are similar to the results reported by Dahiya et al. (2015). Boiling dehulled mung beans resulted in significantly higher protein and fat content, but significantly lower ash content on a dry basis $(p<0.05)$ compared to raw beans. This was similar to what was reported by El-Moniem (1999). Removal of seed coat, which contained less protein and fat, would proportionally increase protein and fat in the dehulled seeds. Furthermore, the loss of soluble solids through boiling into water might improve the protein, fat, and total dietary fibre concentration in cooked seeds. Our findings are consistent with those of Wang et al. (2010) who demonstrated that cooking various beans and chickpeas in boiling water could significantly enhance protein, fat, and total dietary fibre content. The decrease in ash content might be attributed to the diffusion of certain minerals into the cooking water (Mubarak, 2005).

Cooking or boiling of beans is the most common method of preparation in a home setting. It decreases most of the naturally occurring anti-nutritional factors as shown in Table 1. Trypsin inhibitor activity was found to be 15.47 
$\mathrm{TIU} / \mathrm{mg}$ protein in raw mung beans, a value which was similar to that reported by Dahiya et al. (2015). Due to its thermolabile nature, trypsin inhibitor was completely destroyed by the boiling (Mubarak, 2005). It has been suggested that trypsin inhibitor was inactivated and destroyed by moist heat but not dry heat. Decreases in trypsin inhibitor levels would also be due to leaching that occurred during soaking and cooking in water (Dahiya et al., 2015).

Boiling significantly decreased tannin and phytic acid content by $60-73 \%$ and 32-44 \%, respectively. Similarly, Mubarak (2005) reported that boiling reduced the tannin and phytic acid content of mung bean seeds by $46 \%$ and $25 \%$, respectively. The reduction in phytic acid content during cooking or autoclaving might be due to the loss of divalent metals (potassium, calcium, phosphorus, magnesium, iron, and manganese) which bind as the phytatecation protein complex demonstrated by Mubarak (2005). It is possible that mung beans that are pre-soaked and dehulled prior to undergoing hydrothermal treatment may reduce that complex even further. The present study showed that the combination of soaking and dehulling of mung beans lowered the phytic acid content compared with all other treatments. However, the reduction in the tannin content was higher in cooked whole mung beans than in dehulled mung beans. These slight differences were likely caused by the distribution of condensed tannin, which is more abundant in the cotyledons of mung beans than their seed coats (Luo et al., 2016). The protein digestibility can be improved when the anti-nutritional factors are decreased by cooking methods (Mubarak, 2005).

\section{Amino acid composition}

GC-MS has been widely used for amino acid analysis in food due to its high- resolution simplicity of operation and speed of analysis (Jimenez-Martin et al., 2012). The amino acid composition of raw and treated mung beans is presented in Table 2, along with the amino acid profiles of casein and the patterns of IAA requirements for children and adults for comparison, as suggested by the FAO (2013). Mung beans were abundant in all IAAs except sulphur amino acids, when compared with the FAO (2013) reference. The methionine content of raw mung beans in the present study was $0.95 \mathrm{~g} / 100 \mathrm{~g}$ protein which was within the range of $0.5-1.9 \mathrm{~g} / 100 \mathrm{~g}$ protein that was reported by Dahiya et al. (2015). The content of other amino acids, except cystine, histidine and aspartic acid, were also in agreement with this report. These differing results may be attributed to the different methods used for amino acid analysis by GC-MS in this study.

Casein, which was used a reference food protein, matched with all IAAs when compared with the FAO (2013) reference pattern for adults. However, when compared with reference pattern for children, it did not match with sulphur amino acids. The foremost amino acids in casein were histidine, glutamic acid, and proline. This study showed that casein contained significantly higher amounts of isoleucine, valine, methionine, tyrosine, threonine, glutamic acid and proline than all mung bean treatments. Nevertheless, the contents of lysine, phenylalanine, alanine, aspartic acid, and glycine in casein were lower than treated mung bean.

The results of this study indicated that boiling either soaked or unsoaked beans caused a slight increase in total IAAs. They were consistent with the results of the study by El-Moniem (1999) for mung bean seeds, and that of Alajajai \& El-Adawy (2006) for chickpea seeds. The small increase in total amino acid content after boiling is similar to the increase in protein content after 
Prachansuwan A, Kriengsinyos W, Judprasong $K$ et al.




cooking. These results varied from that of Mubarak (2005) who reported that all thermal processes such as boiling, autoclaving, and microwave cooking did not increase in total IAAs.

Several studies have shown that cooking decreased lysine and total aromatic amino acids, which may be explained by destruction, Maillard reaction, and cross-linkage reactions (Alajaji \& El-Adawy, 2006). However, the present study found that boiled mung bean seeds were still higher in lysine and total aromatic amino acids which were similar to the results from study of El-Moniem (1999) which revealed that cooking mung beans at $100^{\circ} \mathrm{C}$ for $38.6 \mathrm{~min}$ increased the phenylalanine and tyrosine by 5.01-10.91\% when compared with raw seeds. Consistent with this result, Nosworthy et al. (2018) reported that boiling red and green lentils for 25-35 min had higher lysine and phenylalanine content when compared with untreated samples. In contrast, Mubarak (2005) and Alajajai \& El-Adawy (2006) reported that boiling at $100^{\circ} \mathrm{C}$ for 90 min slightly decreased lysine and total aromatic amino acids contents. Igwe et al. (2012) showed that boiling at $100^{\circ} \mathrm{C}$ for $12 \mathrm{~h}$ significantly $(p<0.05)$ reduced lysine in Prosopis africana and Ricinus communis. This may imply that the length of boiling treatment or prolonged cooking also contributed to the alteration of amino acid composition in mung bean seeds.

\section{Protein and amino acid digestibility}

Digestibility is a critical major factor affecting the quality of dietary plant proteins. When certain peptide links are not hydrolysed in the digestive process, part of the protein is either excreted in faeces, or transformed into a metabolic product by gut microorganisms present in the large intestine (van der Wielen, Moughan \& Mensink, 2017). Protein quality evaluation measures the proportion of amino acids that can be absorbed from the diet and utilized in the body. An in vitro digestion procedure was used to determine protein digestibility in this study. This method was compared with true faecal protein digestibility in rodents and found to have a significantly high correlation $(p<0.001)$ (Rozan et al., 1997).

The preparation step of oven-drying and grinding of samples before in vitro digestion, which used in our current study, was similar to that used in other studies (Mubarak, 2005; Ghavidel \& Prakash, 2007; Kalpanadevi \& Mohan, 2013). The hot air oven-drying at $50^{\circ} \mathrm{C}$ during the sample preparation should not have any effects on protein digestibility since the drying at $50^{\circ} \mathrm{C}$ does not result in conformational changes of the protein. Based on the study of Bax et al. (2012), protein will change its conformation at a temperature of $70^{\circ} \mathrm{C}$ and that will, in turn, increase pepsin hydrolysis. The grinding of samples was performed to simulate the mechanical digestion at the mouth by teeth. Thus, oven-drying and grinding of samples may be used for the sample preparation in the in vitro digestibility studies.

The raw mung beans had the lowest protein digestibility among all treatments (Table 3), whereas casein presented the highest protein digestibility. The domestic cooking methods of mung beans improved protein digestibility by approximately $11 \%$. Similar results were obtained by Barroga, Laurena \& Mendoza (1985) and Mubarak (2005) who showed that protein digestibility improved by about $8-13 \%$. The improvement in protein digestibility of mung beans by thermal cooking may be attributed to the destruction or removal of anti-nutritional factors, resulting in the easier release of nutrients than raw beans and the alteration of protein structure through denaturation. Protein denaturation by thermal treatment 
Table 3. Amino acid digestibility (\%) and in vitro protein digestibility (\%) of raw and cooked mung bean after a 6-hour enzymatic digestion

\begin{tabular}{|c|c|c|c|c|c|}
\hline \multirow[b]{2}{*}{ Protein and amino acids } & \multirow[b]{2}{*}{ Raw } & \multicolumn{3}{|c|}{ Cooked } & \multirow[b]{2}{*}{ Casein } \\
\hline & & Unsoaked & Soaked & $\begin{array}{l}\text { Soaked\& } \\
\text { Dehulled }\end{array}$ & \\
\hline \multicolumn{6}{|l|}{ Indispensable amino acids (IAA) } \\
\hline \multicolumn{6}{|c|}{ Branched-chain amino acid (BCAA) } \\
\hline Isoleucine & $50.2^{\mathrm{ab}}$ & $53.7^{\mathrm{b}}$ & $60.0^{c}$ & $54.8^{\mathrm{bc}}$ & $47.5^{\mathrm{a}}$ \\
\hline Leucine & $60.6^{\mathrm{a}}$ & $63.1^{\mathrm{ab}}$ & $69.3^{\mathrm{ab}}$ & $65.7^{\mathrm{ab}}$ & $74.9^{b}$ \\
\hline Valine & $64.5^{\mathrm{ab}}$ & $63.5^{\mathrm{ab}}$ & $69.8^{\mathrm{ab}}$ & $71.9^{\mathrm{b}}$ & $59.8^{\mathrm{a}}$ \\
\hline \multicolumn{6}{|l|}{ Sulphur amino acids (SAA) } \\
\hline Methionine & $52.4^{\mathrm{a}}$ & $42.0^{\mathrm{bc}}$ & $48.0^{\mathrm{ab}}$ & $36.8^{c}$ & $51.6^{\mathrm{a}}$ \\
\hline Cystine & ND & ND & ND & ND & ND \\
\hline \multicolumn{6}{|l|}{ Aromatic amino acids (AAA) } \\
\hline Phenylalanine & $36.8^{\mathrm{a}}$ & $46.8^{b}$ & $39.5^{\mathrm{a}}$ & $44.7^{\mathrm{b}}$ & $60.6^{c}$ \\
\hline Tyrosine & ND & ND & $\mathrm{ND}$ & ND & 79.2 \\
\hline Lysine & $57.9^{\mathrm{a}}$ & $52.9^{\mathrm{ab}}$ & $53.4^{\mathrm{ab}}$ & $49.3^{b}$ & $70.2^{\mathrm{c}}$ \\
\hline Threonine & $45.3^{\mathrm{a}}$ & $56.4^{\mathrm{b}}$ & $52.7^{\mathrm{bc}}$ & $54.1^{\mathrm{bc}}$ & $50.5^{\mathrm{ac}}$ \\
\hline Histidine & $26.4^{\mathrm{a}}$ & $53.1^{\mathrm{b}}$ & $50.1^{c}$ & $48.8^{c}$ & $70.4^{\mathrm{d}}$ \\
\hline Mean of BCAA & $58.4^{\mathrm{a}}$ & $60.1^{\mathrm{ab}}$ & $66.4^{b}$ & $64.1^{\mathrm{ab}}$ & $60.7^{\mathrm{ab}}$ \\
\hline Mean of IAA & $49.3^{\mathrm{a}}$ & $53.9^{\mathrm{bc}}$ & $55.4^{c}$ & $53.3^{\mathrm{b}}$ & $62.7^{\mathrm{d}}$ \\
\hline \multicolumn{6}{|l|}{ Dispensable amino acids (DAA) } \\
\hline Alanine & $52.3^{\mathrm{a}}$ & $63.7^{\mathrm{cd}}$ & $54.7^{\mathrm{ab}}$ & $59.5^{\mathrm{bc}}$ & $66.6^{\mathrm{d}}$ \\
\hline Arginine & ND & ND & ND & ND & ND \\
\hline Aspartic acid & $23.4^{\mathrm{a}}$ & $34.1^{\mathrm{b}}$ & $27.0^{c}$ & $32.0^{\mathrm{d}}$ & $39.5^{\mathrm{e}}$ \\
\hline Glutamic acid & $28.1^{\mathrm{a}}$ & $35.9^{\mathrm{b}}$ & $29.3^{a}$ & $35.0^{\mathrm{b}}$ & $35.9^{b}$ \\
\hline Glycine & $39.7^{\mathrm{a}}$ & $54.7^{\mathrm{b}}$ & $50.9^{b}$ & $55.5^{\mathrm{b}}$ & $70.1^{c}$ \\
\hline Serine & $18.7^{\mathrm{a}}$ & $40.1^{\mathrm{b}}$ & $37.8^{\mathrm{b}}$ & $38.7^{\mathrm{b}}$ & $41.6^{b}$ \\
\hline Proline & $44.4^{a}$ & $54.7^{\mathrm{b}}$ & $61.5^{\mathrm{bc}}$ & $57.0^{\mathrm{b}}$ & $64.0^{c}$ \\
\hline Mean of DAA & $34.4^{\mathrm{a}}$ & $47.2^{\mathrm{b}}$ & $43.5^{c}$ & $46.3^{b}$ & $52.9^{d}$ \\
\hline Mean of total amino acids & $42.9^{\mathrm{a}}$ & $51.1^{\mathrm{b}}$ & $50.3^{\mathrm{b}}$ & $50.3^{b}$ & $58.8^{c}$ \\
\hline Protein digestibility & $37.9^{\mathrm{b}}$ & $49.9^{a}$ & $48.2^{\mathrm{ab}}$ & $48.7^{\mathrm{a}}$ & $58.4^{\mathrm{a}}$ \\
\hline $\begin{array}{l}\text { Relative protein digestibility } \\
\text { (compared with casein) }\end{array}$ & $65.2^{\mathrm{b}}$ & $85.4^{\mathrm{c}}$ & $82.2^{\mathrm{c}}$ & $83.3^{\mathrm{c}}$ & $100.0^{\mathrm{a}}$ \\
\hline
\end{tabular}

Data were shown as mean of three independent analyses for protein digestibility and mean of two independent analyses for amino acids. The values within the same row with different superscript letters showed significantly differences between treatments at $p<0.05$, by one-way ANOVA with Tukey test.

could also increases polypeptide chain flexibility and accessibility to attack by proteolytic enzymes (Negi, Boora \& Khetarpaul, 2001).

Soaking and/or dehulling mung beans before cooking did not further improve protein digestibility. The protein digestibility of cooked mung beans was $48-50 \%$, which was around
$82-85 \%$ relative to that of casein. These results were consistent with those of Embaby (2010) who showed that soaking and dehulling did not affect the protein digestibility of cooked sweet lupin. However, that study showed improvement in protein digestibility of soaked and dehulled bitter lupin. Similarly, Kalpanadevi \& Mohan (2013) 
showed that there was no difference in protein digestibility after cooking unsoaked and soaked seeds. By contrast, soaking and/or dehulling of moth beans prior to pressure cooking improved protein digestibility by $3-6 \%$ when compared to the pressure cooking of unsoaked beans (Negi et al., 2001). Deol \& Bains (2010) found that the protein digestibility of pressure-cooked cowpea pods was slightly higher than boiled peas. These results may be attributed to the difference in cooking methods such as boiling and pressure-cooking.

For the determination of biological availability of protein in foods, the FAO/ WHO Expert Consultation on Protein Quality Evaluation report recommended the use of the DIAAS by considering the true ileal digestibility of individual amino acids (FAO, 2013). To determine the amino acid digestibility, we simulated the intestinal absorption by using in vitro dialysis digestion. Amino acid digestibility of mung beans is shown in Table 3. The amino acid digestibility of mung beans also reflects the quality of its protein. When the amino acid digestibility of cooked mung beans was compared with that of casein, it was observed that they had lower the total amino acid digestibility than casein. Among mung bean treatments, soaked and boiled mung bean seemed to have the highest IAAs digestibility, which was $55.4 \%$.

All mung bean treatment methods had similar branched-chain amino acid digestibility when compared to that of casein. Soaked mung beans and those that were soaked and dehulled exhibited isoleucine digestibility of $60.0 \%$, and $54.8 \%$ and valine digestibility of $69.8 \%$, and $71.9 \%$, respectively, which were higher than those available from casein. These results were consistent with those of Brulé \& Savoie (1988) who reported that isoleucine and valine digestibility of field peas, rapeseeds, and soybeans were higher than that of casein. However, phenylalanine and lysine digestibility of cooked mung beans was lower than those of casein even though the former contained more phenylalanine and lysine. Lysine and methionine digestibility tended to decrease after boiling whereas phenylalanine, threonine and histidine digestibility slightly increased after hydrothermal treatments.

In heat-processed food, methionine, cysteine, and lysine can be oxidized or react with compounds to form unavailable derivatives such as methionine sulphoxide, methionine sulphone, as well as cysteic acid. Rutherfurd \& Moughan (2012) also reported that the available amino acid content determined by the difference between ingested amino acid and remaining undigested amino acid at terminal ileum may not be accurate because the unabsorbed amino acids contained in foods can revert to available forms during hydrolysis step of analysis leading to overestimation of available amino acids. Furthermore, for determining true ileal amino acid digestibility, the endogenous losses of amino acids need to be considered. These losses depend on the contents of dietary fibre, body weight of animal models and the alteration of bacterial nitrogen. Endogenous ileal amino acid losses are significant especially in malnourished people, elderly and patients with inflammatory bowel diseases (Gaudichon et al., 2002).

Consequently, these factors may cause changes in the amino acid composition of ileal fluid and lead to a biased estimation of the endogenous amino acid loss. Therefore, an in vitro digestion procedure might overcome the downside of true ileal digestibility method due to the difference in the sample collection from dialysate (available) and digesta (unavailable), and reduce the bias in endogenous losses of amino acids. 


\section{Protein quality determination}

The AAS and the DIAAS for the determination of protein quality are presented in Figure 1. The AAS and DIAAS values of soaked and cooked mung beans were 0.39 and 0.19 , respectively for the sulphur amino acids. These scores indicated that AAS was higher than DIAAS, which was due to the digestibility correction. It may imply that the digestibility measurement of each amino acid is very important especially for plant protein. Similar results were obtained by Nosworthy et al. (2018) for red and green lentils. Our results indicated that the value of AAS did not reflect the quality of plant-based protein. According to the recommendation of the FAO (2013), DIAAS is a recent method that is used to measure the protein quality; however, this approach is based on ileal digestibility, which is very invasive rather than faecal digestibility.

The DIAAS values of raw, unsoaked, soaked, soaked and dehulled boiled mung beans were $0.18,0.17,0.19$, and 0.16 , respectively for the sulphur amino acids, which had no difference among all mung bean treatments. These results were in agreement with those of the study by Hodgkinson et al. (2018)

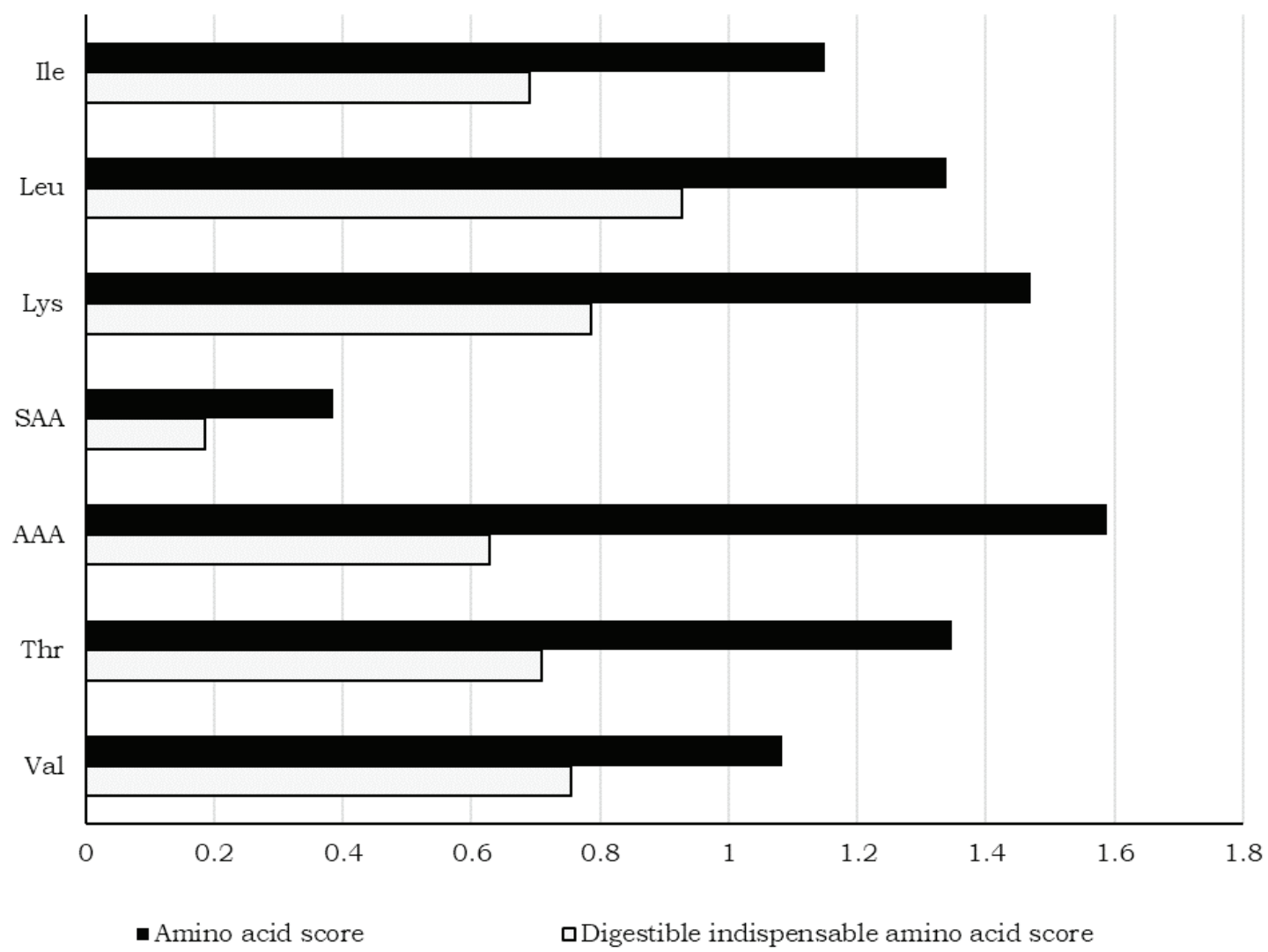

Figure 1. Protein quality determination of soaked cooked mung bean

Data were calculated using the reference pattern for children aged 6 months to $<3$ years. Ile: Isoleucine, Leu: Leucine, Lys: Lysine, SAA: Sulphur Amino Acid, AAA: Aromatic Amino Acid, Thr: Threonine, and Val: Valine. 
who determined the effect of cooking processes on DIAAS of beef. They found that the DIAAS did not differ between raw and boiling meat but was lower in grilled and roasted beef. Consistent with these results, the previous study of Nosworthy et al. (2018) revealed that baking exhibited lower DIAAS than boiling and extrusion of legumes. It may be concluded that DIAAS would differ when the severe thermal cooking processes such as baking, grilling, and roasting are performed, but would not differ after boiling.

\section{CONCLUSION}

The processing techniques of soaking and dehulling prior to boiling increased the in vitro amino acid digestibility of mung beans, especially those of branchedchain amino acids. However, they did not further improve the overall quality of proteins determined by DIAAS. It could be due to the fact that boiling was not a severe thermal cooking method. The present findings concluded that boiling, where the cooking temperature does not exceed $100^{\circ} \mathrm{C}$, is a good hydrothermal cooking procedure and it does not affect the protein quality. Mung beans were shown to have a small amount of sulphurcontaining amino acids. As such, complementary amino acids from other food sources are needed for ensuring adequacy of these amino acids. This study did not determine the tryptophan concentrations of all samples due to the limitation of the amino acid analysis method. The in vitro digestion method should be further validated in terms of amino acid digestibility and compared with in vivo method to determine true ileal amino acid digestibility. However, the in vivo technique in animals or humans is invasive, costly, requires specific instruments and is time-consuming.

\section{Acknowledgement}

The authors are thankful to Faculty of Graduate Studies, Mahidol University for partially supporting the research assistantship in the academic year 2017 and to the Department of Physiology, Faculty of Veterinary Medicine, Kasetsart University for allowing us the use of its facilities to conduct this study. In addition, we would like to thank Ms. Christine Stanly at Institute of Nutrition, Mahidol University for her helpful comments during manuscript preparation.

\section{Authors' contributions}

AP, performed the study, analysed the data and drafted the manuscript; WK, designed the study, conducted the data interpretation, and reviewed the manuscript; JK, designed the methodology and analysed the data; AK, advised on the methodology and the data analysis; PC, advised on the methodology.

\section{Conflict of interest}

The authors declared no conflict of interest.

\section{References}

AACC International (1999). Measurement of Trypsin Inhibitor Activity of Soy ProductsSpectrophotometric Method (11th ed.). Publ. American Association of Cereal Chemists International, St. Paul, MN, USA.

Alajaji SA \& El-Adawy TA (2006). Nutritional composition of chickpea (Cicer arietinum L.) as affected by microwave cooking and other traditional cooking methods. J Food Compost Anal 19:806-812.

AOAC International (2016). Official Methods of Analysis of AOAC International (20th ed.). Publ AOAC International, Rockville, MD, USA.

Arsenault JE \& Brown KH (2017). Effects of protein or amino-acid supplementation on the physical growth of young children in lowincome countries. Nutr Rev 75:699-717.

Barroga CF, Laurena AC \& Mendoza EMT (1985). Effect of condensed tannins on the in vitro protein digestibility of mungbean (Vigna radiata (L.) Wilczek). J Agric Food Chem 33:1157-1159.

Bax ML, Aubry L, Ferreira C, Daudin JD, Gatellier P, Rémond D \& Santé-Lhoutellier V (2012). Cooking temperature is a key determinant of in vitro meat protein digestion rate: investigation of underlying mechanisms. J Agric Food Chem 60: 2569-2576. 
Brulé D \& Savoie L (1988). In vitro digestibility of protein and amino acids in protein mixtures. $J$ Sci Food Agric 43:361-372.

Burns RE (1971). Method for estimation of tannin in grain sorghum. Agron J 63:511-512.

Candela M, Astiasaran I \& Bello J (1997). Cooking and warm-holding: effect on general composition and amino acids of kidney beans (Phaseolus vulgaris), chickpeas (Cicer arietinum), and lentils (Lens culinaris). J Agric Food Chem 45:4763-4767.

Dahiya PK, Linnemann AR, Van Boekel MAJS, Khetarpaul N, Grewal RB \& Nout MJR (2015). Mung bean: technological and nutritional potential. Crit Rev Food Sci Nutr 55:670-688.

Deol JK \& Bains K (2010). Effect of household cooking methods on nutritional and anti nutritional factors in green cowpea (Vigna unguiculata) pods. J Food Sci Technol 47:579581.

Devi S, Varkey A, Sheshshayee MS, Preston T \& Kurpad AV (2018). Measurement of protein digestibility in humans by a dual-tracer method. Am J Clin Nutr 107: 984-991.

El-Moniem GMA (1999). Sensory evaluation and in vitro protein digestibility of mung bean as affected by cooking time. $J$ Sci Food Agric 79:2025-2028.

Embaby HES (2010). Effect of soaking, dehulling, and cooking methods on certain anti-nutrients and in vitro protein digestibility of bitter and sweet lupin seeds. Food Sci Biotechnol 19:10551062 .

FAO (2002). Food energy - methods of analysis and conversion factors: Report of a Technical Workshop. Food and nutrition paper 77. Food and Agriculture Organization, Rome, Italy.

FAO (2013). Dietary protein quality evaluation in human nutrition: Report of an FAO Expert Consultation. Food and nutrition paper 92. Food and Agriculture Organization, Rome, Italy.

Gao Y (2007). A modified colorimetric method for phytic acid analysis in soybean. Crop Sci 47:1797-1803.

Gaudichon C, Bos C, Morens C, Petzke KJ, Mariotti F, Everwand J, Benamouzig R, Dare S, Tome D \& Metges CC (2002). Ileal losses of nitrogen and amino acids in humans and their importance to the assessment of amino acid requirements. Gastroenterology 123:50-59.
Ghavidel RA \& Prakash J (2007) The impact of germination and dehulling on nutrients, antinutrients, in vitro iron and calcium bioavailability and in vitro starch and protein digestibility of some legume seeds. LWT - Food Sci Technol 40: 1292-1299.

Gilani GS, Xiao CW \& Cockell KA (2012). Impact of antinutritional factors in food proteins on the digestibility of protein and the bioavailability of amino acids and on protein quality. $\mathrm{Br} J \mathrm{Nutr}$ 108:S315-S332.

Henchion M, Hayes M, Mullen AM, Fenelon M \& Tiwari B (2017). Future Protein Supply and Demand: Strategies and Factors Influencing a Sustainable Equilibrium. Foods 6:53.

Hodgkinson SM, Montoya CA, Scholten PT, Rutherfurd SM \& Moughan PJ (2018). Cooking conditions affect the true ileal digestible amino acid content and digestible indispensable amino acid score (DIAAS) of bovine meat as determined in pigs. The Journal of nutrition 148:1564-1569.

Igwe CU, Ojiako OA, Anugweje KC, Nwaogu LA $\&$ Ujowundu CO (2012). Amino acid profile of raw and locally processed seeds of Prosopis africana and Ricinus communis: potential antidotes to protein malnutrition. Functional Foods in Health and Disease 2:107-119.

Jimenez-Martin E, Ruiz J, Perez-Palacios T, Silva A \& Antequera T (2012). Gas chromatographymass spectrometry method for the determination of free amino acids as their dimethyl-tert-butylsilyl (TBDMS) derivatives in animal source food. J Agric Food Chem 60:2456-63.

Kalpanadevi V \& Mohan VR (2013). Effect of processing on antinutrients and in vitro protein digestibility of the underutilized legume, Vigna unguiculata (L.) Walp subsp. unguiculata. LWTFood Science and Technology 51:455-461.

Luo J, Cai W, Wu T \& Xu B (2016). Phytochemical distribution in hull and cotyledon of adzuki bean (Vigna angularis L.) and mung bean (Vigna radiate $\mathrm{L}$.), and their contribution to antioxidant, anti-inflammatory and antidiabetic activities. Food Chem 201:350-360.

Mubarak AE (2005). Nutritional composition and antinutritional factors of mung bean seeds (Phaseolus aureus) as affected by some home traditional processes. Food Chem 89:489-495. 
Negi A, Boora P \& Khetarpaul N (2001). Effect of microwave cooking on the starch and protein digestibility of some newly released moth bean (Phaseolus aconitifolius Jacq.) Cultivars J Food Compost Anal 14:541-546.

Nosworthy MG, Medina G, Franczyk AJ, Neufeld J, Appah P, Utioh A, Frohlich P \& House JD (2018). Effect of processing on the in vitro and in vivo protein quality of red and green lentils (Lens culinaris). Food Chem 240:588-593.

Rozan P, Lamghari R, Linder M, Villaume C, Fanni $\mathrm{J}$, Parmentier M \& Méjean L (1997). In vivo and in vitro digestibility of soybean, lupine, and rapeseed meal proteins after various technological processes. J Agric Food Chem 45:1762-1769.

Rutherfurd SM \& Moughan PJ (2012). Available versus digestible dietary amino acids. Br J Nutr 108:S298-S305.

Siddhuraju P \& Becker K (2005). Nutritional and anti-nutritional composition, in vitro amino acid availability, starch digestibility and predicted glycemic index of differentially processed mucuna beans (Mucuna pruriens var. utilis): an under-utilised legume. Food Chem 91:275-286.

Singh KG, D'souza MR \& Yogitha R (2015). Nutrient content and in vivo reduction of antinutrients of mung bean (vigna radiate 1.) under various processing methods. J Chem Biol Phys Sci 5:1627-1638.

van der Wielen N, Moughan PJ \& Mensink M (2017). Amino acid absorption in the large intestine of humans and porcine models. J Nutr 147:1493-1498.

Wang N, Hatcher DW, Tyler RT, Toews R \& Gawalko EJ (2010). Effect of cooking on the composition of beans (Phaseolus vulgaris L.) and chickpeas (Cicer arietinum L.). Food Res Int 43:589-594. 